\title{
ANALISA KANDUNGAN GIZI TEPUNG KACANG GUDE HITAM (Cajanus cajan) DENGAN BEBERAPA PERLAKUAN PENDAHULUAN
}

\author{
Analysis of the Nutritional Content of Black Pigeon Pea Flour Subjected \\ to Several Pre-Treatments
}

Gelora H. Augustyn, Erynola Moniharapon, dan Sani Resimere

\author{
Jurusan Teknologi Hasil Pertanian, Fakultas Pertanian, Universitas Pattimura \\ Jl. Ir. M. Putuhena, Kampus Poka, Ambon 97233
}

\begin{abstract}
This study was aimed to determine the nutrient content of the black pigeon pea flour that has been subjected to several pre-treatments. A completely randomized experimental design was applied in this study that consisted of four levels of treatments replicated 3 times. The results showed that either moisture, protein, fat, carbohydrate, or fiber content were significantly influenced by pre-treatments on processing of the black pigeon pea flour. However, the ash content was not significantly affected. The best result was obtained by $\mathrm{A}_{2}$ treatment that produced the black pigeon pea flour with the moisture, ash, protein, fat, carbohydrate and fiber contents of $6.16 \%, 0.94 \%, 24.32 \%, 2.94 \%, 65.64 \%$, and $3.21 \%$, respectively.
\end{abstract}

Keywords: black pigeon pea, black pigeon pea flour, chemical composition

\begin{abstract}
ABSTRAK
Penelitian ini bertujuan untuk mengetahui kandungan gizi tepung kacang gude hitam dengan beberapa perlakuan pendahuluan penelitian ini menggunakan rancangan acak lengkap yang terdiri dari empat taraf perlakuan dan tiga ulangan. Hasil penelitian menunjukan bahwa kadar air, kadar protein, kadar lemak, kadar karbohidrat dan kadar serat berpengaruh nyata terhadap tepung kacang gude hitam namun tidak berpengaruh nyata terhadap kadar abu. Perlakuan terbaik adalah perlakuan $\mathrm{A}_{2}$ menghasilkan tepung kacang gude hitam dengan kadar air 6,16\%, kadar abu 0,94\%, kadar protein 24,32\%, kadar lemak 2,94\% kadar karbohidrat $65,64 \%$, dan kadar serat $3,21 \%$.
\end{abstract}

Kata kunci: kacang gude hitam, komposisi kimia, tepung kacang gude hitam

\section{PENDAHULUAN}

Kacang gude (Cajanus cajan) adalah sejenis tanaman kacang-kacangan yang bersifat tahunan. Bijinya dapat dimakan dan menjadi sumber pangan alternatif. Pemantapan ketahanan pangan mempunyai peran strategis dalam pembangunan nasional karena akses terhadap pangan dengan gizi yang cukup merupakan hak asasi manusia, kualitas pangan dan gizi yang dikonsumsi merupakan penentu bagi pembentukan sumberdaya manusia yang berkualitas. Oleh karena itu, diperlukan ketersediaan pangan yang cukup, aman, bermutu, bergizi dan beragam dengan harga yang terjangkau masyarakat dan diutamakan berasal dari pangan lokal.

Diversifikasi pangan lokal sangat penting untuk meningkatkan ketahanan pangan masyarakat. Diversifikasi pangan lokal khususnya kacangkacangan lokal yang potensial perlu dikembangkan, karena banyak orang mengkonsumsi mengingat kandungan gizinya tinggi dan produksinya banyak bila dibandingkan dengan kacang-kacangan lokal lainnya seperti kacang merah, kacang tanah, kacang hijau dan kacang-kacangan lainnya. Jenis dari kacang-kacangan ini dibuat tepung dan bisa dibuat 
produk lainnya sehingga meningkatkan nilai gizinya.

Kacang gude tergolong tanaman kacangkacangan yang cukup potensial untuk dikembangkan sebagai bahan pangan yang adaptif lokasi. Hal ini karena nilai gizi yang tidak kalah tinggi dibandingkan kacang-kacangan lain seperti kacang hijau. Sampai saat ini pemanfaatan kacang gude umumnya terbatas sebagai sayuran dan lauk pauk. Padahal kacang gude mempunyai sifat yang mirip kedelai dan nilai gizi yang tidak jauh berbeda, sehingga kacang gude dapat digunakan sebagai subtitusi pada beberapa produk yang terbuat dari kedelai. Polongnya yang masih muda digunakan sebagai lalap, ataupun rujak, bijinya yang sudah tua digoreng dan bisa juga dibuat tepung.

Melalui perkembangan teknologi pengolahan maka perlu dilakukan diversifikasi produk. Salah satu bentuk produk olahan yang perlu dikembangkan adalah pengolahan kacang gude hitam menjadi tepung. Tepung merupakan salah satu bentuk alternatif produk setengah jadi yang dianjurkan, karena lebih tahan disimpan, mudah dicampur (dibuat komposit), ditambah zat gizi (difortifikasi), dibentuk, dan lebih cepat dimasak sesuai tuntutan kehidupan modern yang serba praktis (Winarno, 2000).

Beberapa penelitian menunjukkan bahwa proses perendaman, perebusan, dan pengupasan kulit dapat mengurangi kandungan senyawa anti gizi yang ada dalam tanaman-tanaman leguminosa (Mohamed et al., 2011). Merebus merupakan salah satu metode pengolahan dengan panas basah. Bahan makanan langsung kontak dengan air panas dalam jangka waktu yang ditentukan. Sedangkan perlakuan pengukusan bahan tidak langsung kontak dengan air, mendapatkan panas dari uap air, sehingga penampakan bahan makanan lebih kering dibanding dengan perebusan. Sangrai merupakan metode pengolahan kering, bahan digoreng tanpa media minyak, sehingga hasil akhir terlihat kering. Dalam penelitian ini dilakukan proses perlakuan pendahuluan dengan perendaman 24 jam dan penyangraian 20 menit, perebusan 10 menit, dan pengukusan 30 menit sesuai dengan penelitian Maros (2009) pada kacang lawa hitam dan Laiyan (2009) pada kacang lawa merah. Kacang gude sebelum dijadikan tepung mengalami proses penyangraian, perebusan, dan pengukusan. Kacang gude setelah melalui perlakuan ini dapat dibuat menjadi tepung.

Kacang gude hitam yang diteliti ini berasal dari Kabupaten Maluku Barat Daya Desa Oirata. Di
Desa Oirata produksi kacang gude hitam cukup banyak dan orang mengkonsumsi itu dalam bentuk dimasak dan dimakan begitu saja sementara dibuat tepung bisa bertahan lama atau diversifikasi olahan lainnya.

Untuk itu tujuan penelitian ini adalah untuk mengolah kacang gude hitam menjadi tepung dan mempelajari kandungan gizi tepung kacang gude hitam dengan beberapa perlakuan pendahuluan.

\section{METODE PENELITIAN}

\section{Bahan}

Bahan utama penelitian ini adalah kacang gude hitam yang peroleh dari Desa Oirata Kabupaten Maluku Barat Daya. Bahan kimia yang digunakan adalah $\mathrm{H}_{2} \mathrm{SO}_{4} \mathrm{Mg}, \mathrm{HgO}, \mathrm{Na}_{2} \mathrm{SO}_{4}, \mathrm{NaOH}$, $\mathrm{H}_{3} \mathrm{BO}_{3}, \mathrm{HCl} 0,02 \mathrm{~N}$, petroleum eter, dan alkohol $95 \%$.

\section{Prosedur Penelitian}

Kacang gude yang dipakai sebanyak $1 \mathrm{~kg}$ kacang kering kemudian dimasukan kedalam baskom dan dilakukan pencucian sampai bersih. Selanjutnya kacang gude yang telah bersih dilakukan perlakuan pendahuluan berdasarkan perlakuan yaitu tanpa perlakuan, penyangraian 20 menit, perebusan 10 menit dan pengukusan 30 menit. Kemudian dihancurkan dengan menggunakan blender setelah itu dilakukan proses pengeringan menggunakan oven yang bertujuan untuk mengurangi kadar air tepung sampai kadar air maksimal 10\%. Selanjutnya dilakukan penepungan dengan menggunakan blender setelah itu hasilnya disaring dengan menggunakan ayakan 80 mesh yang bertujuan untuk mendapatkan tepung kacang gude hitam.

\section{Parameter Pengamatan}

Parameter kimia yang diamati meliputi kadar air metode gravimetri, kadar protein metode kjeldhal, kadar lemak metode soxhlet, kadar abu metode oven, kadar serat kasar dan kadar karbohidrat berdasarkan metode yang dikemukakan oleh (AOAC, 2005).

\section{Analisis Statistik}

Penelitian ini menggunakan Rancangan Acak Lengkap satu faktor dengan tiga kali ulangan. Jika 
berbeda nyata atau sangat nyata dilanjutkan dengan uji beda nyata jujur (BNJ) $(\alpha 0,05)$.

\section{HASIL DAN PEMBAHASAN}

\section{Kadar Air}

Kadar air tepung merupakan salah satu parameter yang sangat berpengaruh terhadap umur simpan tepung. Menurut Collins dan Walter (1982), kadar air suatu produk sangat penting dikendalikan karena akan menentukan daya tahan atau keawetan produk yang bersangkutan pada waktu penyimpanan.

Nilai kadar air tepung kacang gude hitam berdasarkan hasil penelitian pada Gambar 1, terlihat bahwa kadar air tertinggi terdapat pada perlakuan $A_{0}(9,23 \%)$, diikuti dengan perlakuan $A_{2}(6,16 \%)$, $A_{1}(5,93 \%)$, dan $A_{3}(5,31 \%)$. Pada perlakuan $A_{1}$, $\mathrm{A}_{2}$, dan $\mathrm{A}_{3}$, apabila dibandingkan dengan $\mathrm{A}_{0}$ mengalami penurunan sebesar $35,75 \%, 33,26 \%$, $42,47 \%$.

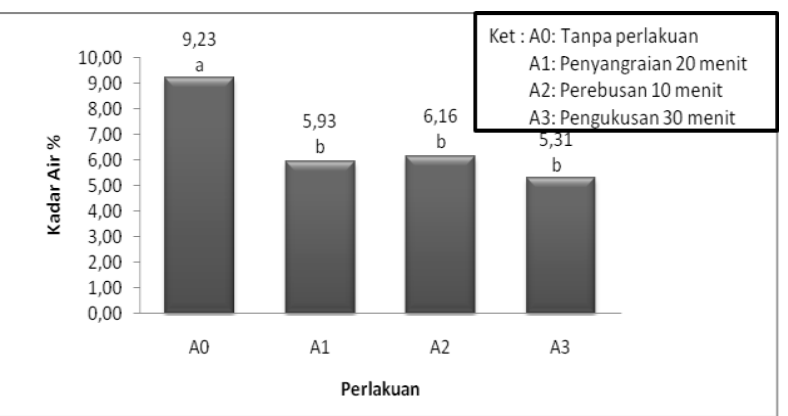

\section{Gambar 1. Histogram Pengaruh Perlakuan Perendaman Terhadap Kadar Air Tepung Kacang Gude Hitam.}

Kadar air merupakan komponen penting dalam menentukan suatu produk pangan. Tepung kacang gude hitam dengan perlakuan pendahuluan berupa perendaman 24 jam memberikan nilai kadar air yang lebih rendah dibandingkan dengan tepung yang diproses tanpa perlakuan pendahuluan. Namun, hasil penelitian menunjukkan bahwa setelah ditepungkan, seluruh perlakuan ternyata menghasilkan kadar air yang berbeda.

\section{Kadar Abu}

Nilai kadar abu tepung kacang gude hitam berdasarkan hasil penelitian pada Gambar 2, terlihat bahwa kadar abu tertinggi terdapat pada perlakuan
$\mathrm{A}_{2}(0,94 \%)$, diikuti dengan perlakuan $\mathrm{A}_{1}(0,76 \%)$ $\mathrm{A}_{0}(0,68 \%), \mathrm{A}_{3}(0,57 \%)$.

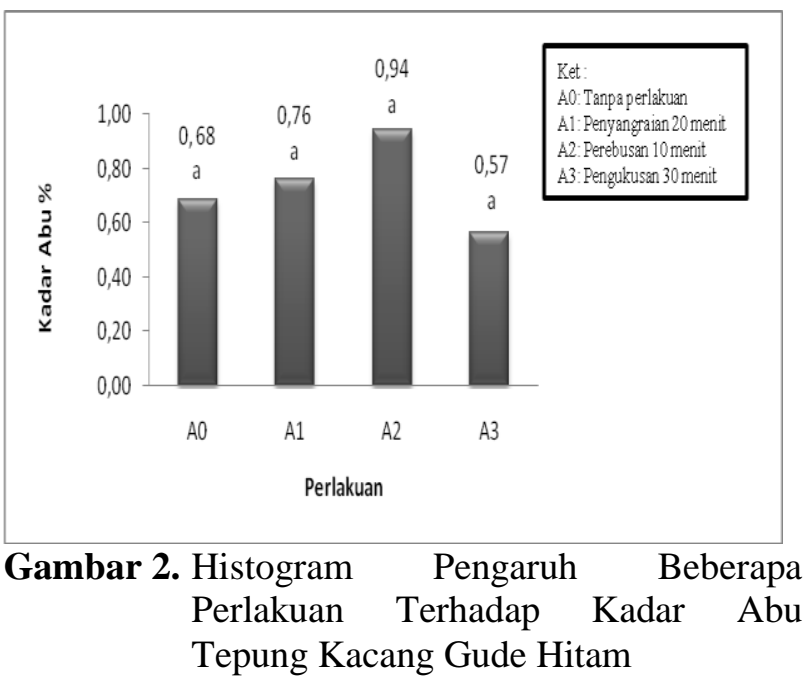

Berdasarkan hasil penelitian yang ditunjukan, terlihat bahwa seluruh perlakuan tidak berpengaruh nyata terhadap kadar abu tepung kacang gude hitam. Menurut Susanto (1994), kadar abu tidak berpengaruh oleh perlakuan fisik maupun kimia hanya hilang sekitar $3 \%$ bagian dari proses pemasakan bahan pangan.

\section{Kadar Protein}

Nilai kadar protein tepung kacang gude hitam berdasarkan hasil penelitian pada Gambar 3, terlihat bahwa kadar protein tertinggi terdapat pada perlakuan $\mathrm{A}_{2}(24,32 \%)$, diikuti dengan perlakuan $\mathrm{A}_{1}(21,48 \%), \mathrm{A}_{3}(22,88 \%)$, dan $\mathrm{A}_{0}(21,48 \%)$. Pada perlakuan $\mathrm{A}_{1}, \mathrm{~A}_{2}$, dan $\mathrm{A}_{3}$. apabila dibandingkan dengan $\mathrm{A}_{0}$ (kontrol) mengalami peningkatan $8,70 \%, 13,22 \%$, dan $6,51 \%$.

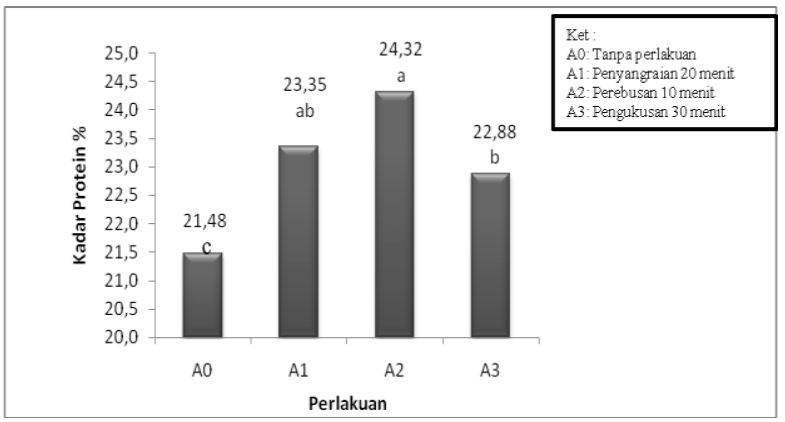

Gambar 3. Histogram Pengaruh Beberapa Perlakuan Terhadap Kadar Protein Tepung Kacang Gude Hitam 
Hasil penelitian menunjukkan bahwa kadar protein berkisar antara $21,48 \%$ sampai dengan $24,32 \%$. Hasil dari analisa bahan awal yaitu sebesar $24,25 \%$, hal ini menunjukan bahwa kandungan protein bahan awal lebih rendah jika dibandingkan dengan setelah diberikan perlakuan pendahuluan yaitu sebesar $24,32 \%$.

Protein merupakan zat yang penting bagi tubuh karena zat ini disamping berfungsi sebagai bahan bakar dalam tubuh juga berfungsi sebagai zat pembangun dan zat pengatur. Protein dapat digunakan sebagai bahan bakar apabila keperluan energi tubuh tidak dipenuhi oleh karbohidrat dan lemak (Winarno, 1993).

\section{Kadar Lemak}

Kadar lemak merupakan salah satu indikator sifat fisik tepung, karena lemak dapat membentuk senyawa komplek dengan senyawa lain, misalnya pati, khususnya amilosa yang dapat menghambat pemecahan molekul lemak, sehingga menghambat juga pengembangan granula pati sehingga sukar terjadi proses gelatinisasi (Munarso et al., 2004).

Nilai kadar lemak tepung kacang gude hitam berdasarkan hasil penelitian pada gambar 4, terlihat bahwa kadar lemak tertinggi terdapat pada perlakuan $\mathrm{A}_{0}(3,64 \%)$, diikuti dengan perlakuan $\mathrm{A}_{1}$ (3,18\%), $\mathrm{A}_{2}(2,94 \%)$, dan $\mathrm{A}_{3}$ (2,80\%). Pada perlakuan $A_{1}, A_{2}$, dan $A_{3}$, apabila dibandingkan dengan $\mathrm{A}_{0}$ mengalami penurunan sebesar $12,60 \%$, $19,23 \%$, dan $23,07 \%$.

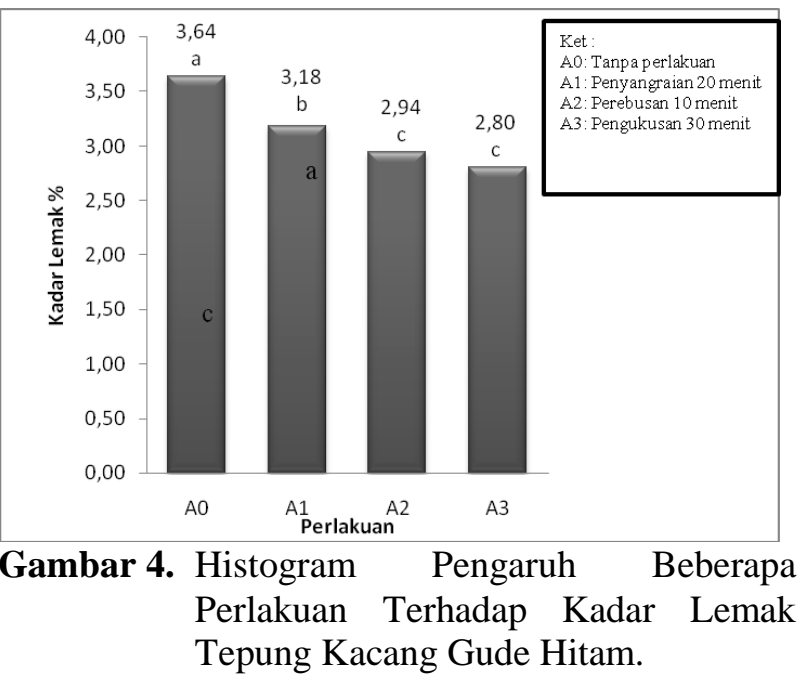

Kadar lemak pada perlakuan $\mathrm{A}_{0}$ meningkat, namun pada perlakuan perendaman 24 jam penyangraian 20 menit, perebusan 10 menit dan pengukusan 30 menit pada tepung kacang gude hitam menurun. Penurunan kadar lemak pada perlakuan pendahuluan ini serupa dengan hasil penelitian yang dilakukan oleh Doss et al. (2011). Terjadi penurunan kadar lemak pada biji koro pedang selama perendaman dari $4,2 \%$ menjadi 4,19\%. Penyebab penurunan lemak pada perlakuan pendahuluan ini adalah karena adanya pelepasan molekul lemak (Audu dan Aremu, 2011).

\section{Kadar Karbohidrat}

Karbohidrat mempunyai peranan penting dalam menentukan karakteristik bahan makanan, misalnya rasa, warna, tekstur, dan lain-lain. Sedangkan dalam tubuh, karbohidrat berguna untuk mencegah timbulnya ketosis, pemecahan protein tubuh yang berlebihan, kehilangan mineral, dan berguna untuk membantu metabolisme lemak dan protein (Winarno, 2002).

Nilai kadar karbohidrat tepung kacang gude hitam berdasarkan hasil penelitian pada Gambar 5, terlihat bahwa kadar karbohidrat tertinggi terdapat pada perlakuan $\mathrm{A}_{3}(68,42 \%)$ diikuti dengan perlakuan $\mathrm{A}_{1}(66,76 \%), \mathrm{A}_{2}(65,64 \%)$, dan $\mathrm{A}_{0}$ $(64,92 \%)$. Pada perlakuan $\mathrm{A}_{1}$ apabila dibandingkan dengan kontrol mengalami kenaikan sebesar 2,83\%, perlakuan $\mathrm{A}_{2}$ apabila dibandingkan dengan $\mathrm{A}_{1}$ mengalami kenaikan sebesar $1,10 \%$, perlakuan $A_{3}$ apabila dibandingkan dengan kontrol mengalami kenaikan sebesar 5,39\%.

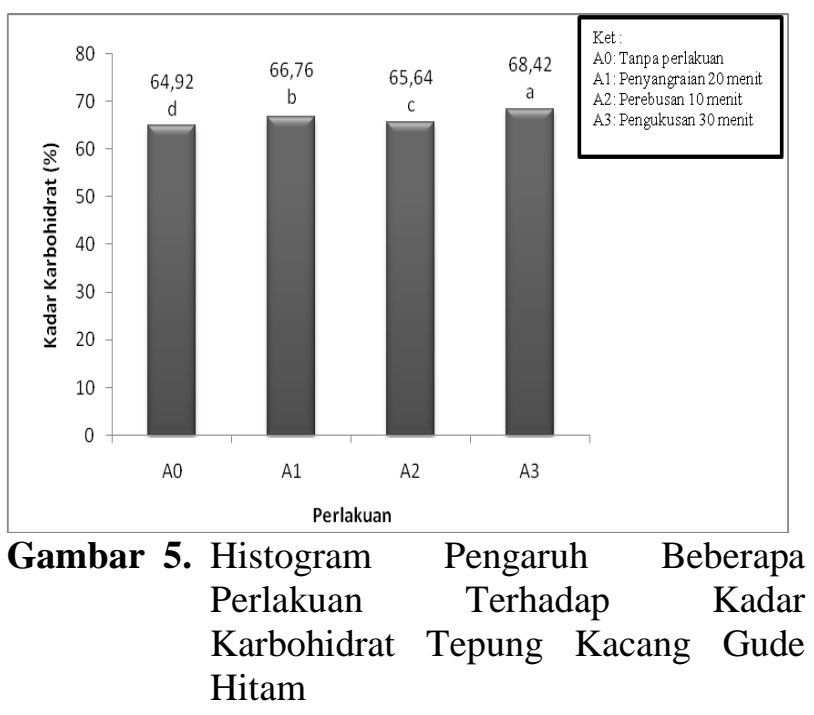

Peningkatan kandungan karbohidrat selama perebusan ini sesuai dengan penelitian yang telah dilakukan oleh Doss et al. (2011) yang menyatakan bahwa terjadi peningkatan kandungan karbohidrat pada koro pedang setelah perebusan. Pada 
perlakuan perendaman, kadar karbohidrat meningkat. Wanjekeche (2010) melaporkan bahwa terjadi kenaikan kadar karbohidrat pada tepung dengan pengupasan kulit pada koro benguk putih dari 54,28\% menjadi 59,0\% dan hal ini juga sesuai dengan penelitian yang dilakukan Ayuningtyas (2012) pada perendaman kacang merah dengan kulit $57,68 \%$ dan meningkat pada perlakuan perendaman tanpa kulit yaitu sebesar 59,49\%.

\section{Kadar Serat Kasar}

Nilai kadar serat tepung kacang gude hitam berdasarkan hasil penelitian pada Gambar 6, terlihat bahwa kadar serat tertinggi terdapat pada perlakuan $\mathrm{A}_{1}(5,41 \%)$ diikuti dengan perlakuan $\mathrm{A}_{3}(3,70 \%)$, $\mathrm{A}_{2}(3,21 \%)$, dan $\mathrm{A}_{0}(2,47 \%)$. Apabila dibandingkan dengan $\mathrm{A}_{0}$ maka $\mathrm{A}_{1}, \mathrm{~A}_{2}$, dan $\mathrm{A}_{3}$, mengalami peningkatan sebesar $119,02 \%, 29,95 \%$, dan $49,8 \%$.

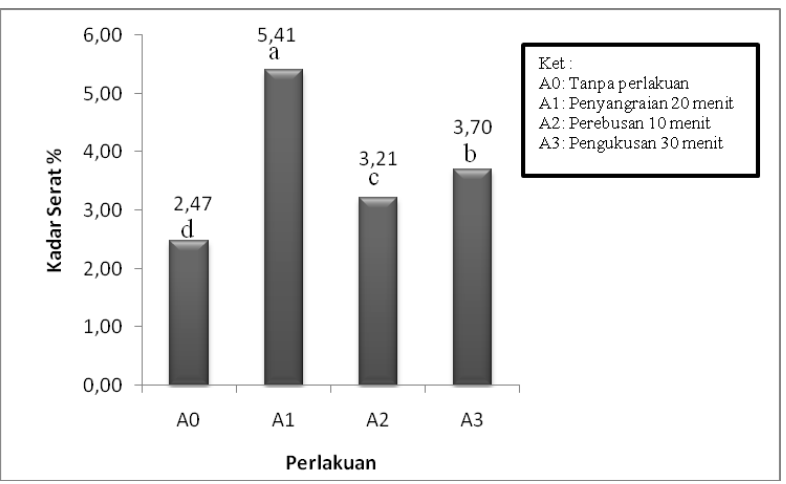

Gambar 6. Histogram Pengaruh Beberapa Perlakuan Terhadap Kadar Serat Tepung Kacang Gude Hitam

Peningkatan kadar serat kasar diakibatkan karena sebagian besar komponen-komponen gizi pada tepung kacang gude hitam yang larut dalam media perendaman dan hanya menyisahkan serat kasar. Terlihat bahwa kadar serat kasar mulai terjadi peningkatan pada perlakuan $\mathrm{A}_{1}$ (perendaman 24 jam dan penyangraian 20 menit) akibat perendaman 24 jam terjadi kehilangan komponen gizi yang larut dalam air perendaman.

Peningkatan yang juga terjadi pada perlakuan $\mathrm{A}_{2}$ (perendaman 24 jam dan perebusan 10 menit) dan $\mathrm{A}_{3}$ (perendaman 24 jam dan pengukusan 30 menit) dimana pengurangan kandungan gizi terjadi lebih besar karena selain perendaman, perebusan dan pegukusan juga memiliki andil yang cukup besar untuk pengurangan kandungan gizi sehingga kadar serat kasar semakin tinggi, karena jika semua kandungan gizi hilang yang tersisa adalah serat kasar.

\section{KESIMPULAN}

Perlakuan terbaik adalah perlakuan $\mathrm{A}_{2}$ (perendaman 24 jam dan perebusan 10 menit) menghasilkan tepung kacang gude hitam dengan kadar air $6,16 \%$, kadar abu $0,94 \%$, kadar protein $24,32 \%$, kadar lemak 2,94\% kadar karbohidrat $65,64 \%$, dan kadar serat $3,21 \%$.

\section{DAFTAR PUSTAKA}

AOAC. 2005. Association of Official Analytical Chemistry. Washington D.C.

Audu, S.S. and M.O. Aremu. 2011. Effect of processing on chemical composition of red kidney bean (Phaseolus vulgaris L.) flour. Pakistan Journal of Nutrition 10: 1069-1075.

Ayuningtyas, H. 2012. Karakterisasi sifat fisik dan kimia tepung kacang merah (Phaseolus Vulgaris L.) dengan beberapa perlakuan pendahuluan. [Skripsi]. Universitas Sebelas Maret. Surakarta.

Collins, W.W. dan W.M. Walter Jr. 1982. Potential for increasing nutritional value of sweet potato. In First Sweet Potato Planning Conference. R. L. Villareal and T. D. Griggs (eds) p 355-363. AVRDC. Shanhua, Taiwan.

Doss. 2011. Effect of processing technique on the nutritional composition and antinutrients content of under utilized food legume canavalia ensiformis L. DC International Food Research Journal 18: 965-970.

Maros, E. 2009 Karakteristik Sifat Kimia Tepung Kacang Lawa Hitam (Phaseolus L.) dengan Beberapa Perlakuan Pendahuluan. [Skripsi]. Universitas Pattimura. Ambon.

Mohamed, R., E.A. Abou-Arab., A.Y. Gibriel, N.M.H. Rasmy, and F.M. Abu-Salem. 2011. Effect of legume processing treatments individually or in combination on their phytic acid content. African Journal of Food Science and Technology 2: 36-46.

Munarso, S.J., D. Muchtadi, D. Fardiaz, dan R. Syarief. 2004. Perubahan sifat fisikokimia dan fungsional tepung beras akibat proses modifikasi ikat-silang. Jurnal Pascapanen 1: 22-28.

Laiyan, D. 2009 Karakteristik Kimia Tepung Kacang Lawa Mereh (Phaseolus Vulgaris L.) 
Dengan Beberapa Perlakuan Pendahuluan. [Skripsi]. Universitas Pattimura. Ambon.

Susanto, T. 1994. Teknologi Pengolahan Hasil Pertanian. Bina Ilmu. Surabaya.

Wanjekeche, E., J.K. Imungi, and E.G. Karuri. 2010. Effect of soaking on the cookability and nutritional quality of mucuna bean. 12th KARI Scientific Conference Proceedings.
Winarno, F.G. 2000. Potensi dan peran tepungtepungan bagi industri pangan dan program perbaikan gizi. Prossiding pada Semimar Nasional: Penganekaragaman Makanan untuk Memantapkan Ketersediaan Pangan. Jakarta.

Winarno, F.G. 1993. Pangan Gizi Teknologi dan Konsumen. Gramedia Pustaka Utama, Jakarta. 